\title{
The social investment litmus test: Family formation, employment and poverty
}

Journal of European Social Policy

$1-15$

(C) The Author(s) 2020

Article reuse guidelines: sagepub.com/journals-permissions DOI: $10.1177 / 0958928720950627$ journals.sagepub.com/home/esp @SAGE

\author{
Ilze Plavgo and Anton Hemerijck \\ European University Institute, Italy
}

\begin{abstract}
Over the past decade, the notion of 'social investment' (SI) has gained considerable traction in the political debates over welfare state futures. The multifaceted character of SI policy interventions, the effects of policy complementarities and interactions for different social groups and generational cohorts, and the challenge of delineating effects across different time dimensions, we argue, are not (yet) properly addressed by current empirical research. This paper contributes to reorienting the measurement of SI returns into a longer-term perspective, conceptualising them as people's work- and welfare- related outcomes. It operationalises in a novel fashion macro-level data across OECD countries to analyse the medium-term aggregate effects of SI stock, flow and buffer policies with a focus on arguably the most critical stages in the post-industrial life-cycle course: transition into employment and family formation. Our findings imply that the so-called 'Matthew effects', following the biblical proverb 'to him that hath shall be given', identified in previous research stem from a measurement of SI returns conceptualised in a short-term redistributive perspective. Moving on to longer-term returns to SI policies at the societal level reveals positive outcomes for families with children.
\end{abstract}

\section{Keywords}

Employment, families with children, life course, OECD, poverty, social investment returns

\section{Social investment returns in dispute}

Since the turn of the century the notion of social investment (SI) has gained considerable attention as a novel welfare compass to address post-industrial economic and social change in an integrated fashion. Even though public social spending levels have consolidated over the past two decades, most European welfare states have been recalibrating and reconfiguring the elementary policy mixes upon which they were built after the Second World War in a social investment direction. In the process, the overarching social policy objective has shifted from consumption smoothing to

\footnotetext{
Corresponding author:

Anton Hemerijck, Department of Political and Social Sciences, European University Institute, Via dei Roccettini 9, 500।4

Fiesole (FI), Italy.

Email: anton.hemerijck@eui.eu
} 
promoting employment participation, although the extent of this shift varies from country to country (Hemerijck, 2017). In a generic sense, SI reform tilts the welfare balance from ex-post compensation in times of economic or personal hardship to ex-ante risk prevention. The objective is one of 'capacitation', hence strengthening human capital and improving work-life balance opportunities with a view to increasing female and older worker participation in the workforce.

The imperative of SI has been taken forward by international organisations, from the European Commission (2019) and the OECD (2014) to the World Bank Group (2016), operating at arm's length from politically salient domestic social politics, as the prerequisite for strategies of 'inclusive growth' in the aftermath of the Great Recession. Among national policy-makers and in academia, SI continues to struggle for recognition as a policy paradigm. Within the political arena, social policies continue to be compartmentalised across sectoral ministries - employment and social affairs, education and healthcare - making it difficult to speak of a coherent social investment paradigm. In academia, research on this topic has gathered steam in both sociology and political science, the two prominent disciplines in comparative welfare state research. There have been important attempts in political science to qualitatively trace the SI turn across countries. Some indication is found that social investment reform is associated with high levels of employment, productivity and growth, social mobility and subdued levels of (child) poverty (Huo, 2009; Kuitto, 2016; Ronchi, 2018; van Kersbergen and Hemerijck, 2012). Political behaviouralists, however, find that popular social protection programmes, especially pensions, tend to crowd out SI reform by constraining political cleavage formation behind SI (Garritzmann et al., 2018). In sociology, the academic reception of SI has been more sceptical, casting doubt on the employment growth and poverty mitigation promises of SI advocacy. In his seminal 2013 article 'What use is "social investment"?' Brian Nolan not only questions the empirical validity of social investment employment growth, but also raises concerns about the normative sway of SI advocacy as a political platform on narrow 'economistic' grounds (Nolan, 2013; 2017). The most pernicious sociological critique comes from Bea Cantillon who conjectures that social investments in the areas of early childhood, family policy and ALMP are plagued with perverse Matthew effects. Cantillon and colleagues infer that SI reforms disproportionately benefit the 'work-rich' middle-class families at the expense of poorer segments in society (Abrassart and Bonoli, 2015; Cantillon, 2011; Cantillon and Van Lancker, 2013).

We argue in this article that when SI policies are understood simply as redistributive cash-transfers, only short-term individual SI returns are assessed. SI returns, however, are expected to reap over a longer period, and not only at an individual but also at an intergenerational and a societal level. Tracking household disposable income before and after SI 'transfers' cannot effectively capture the mid- to long-term effects of SI policy synergies and how they affect people's welfare.

Admittedly, the seminal scientific breakthrough in the study of the 20th-century welfare provision has its origins in Esping-Andersen's (1990) effort to reduce real-world complexity based on the conceptual typology of his "three worlds of welfare capitalism', each with their specific social protection modus operandi, understood in terms of redistributive decommodification. However, the extent to which academic research continues to equate protection decommodification with welfare effort, makes it difficult to grasp how 21st-century welfare states are changing and how this affects life chances in more dynamic ways. An exclusive focus on the redistributive impact fails to capture the gist of the SI paradigm promise of 'flourishing lives' in leveraging employment and welfare in an interdependent fashion, through a combination of complementary policies, across critical life course transitions.

The aim of this article is to redress this academic impasse by gauging the socioeconomic effect of SI policies in terms of employment inclusion and poverty mitigation in the medium term at a societal level focusing on one specific period in the life course: that of transition into employment and family formation. The research question addressed in this article is whether and to what extent SI policy availability explains cross-country variation in work- and welfarerelated life outcomes for families with children. We attempt to answer this question by looking at whether 
the presence of policies geared towards SI is associated with greater economic independence and lower poverty among families with children for both couple- and single-parent households at a macro level. We use aggregate data from the OECD Family Database, OECD Social Expenditure Database and EUROSTAT on 34 high-income OECD countries to measure the relationship between SI policy availability and people's work- and welfare-related life chances. Findings indicate that SI policies are associated with reduced rather than exacerbated gendered employment and economic inequalities. The findings offer an alternative look at the so-called Matthew effect conundrum, indicating that although from the individual short-term perspective SI policies may in some cases disproportionately benefit middleclass families, they can have positive medium-term effects for families with children at an aggregate level.

The article proceeds as follows. First, in the next section we put forth the main functions of SI policies underlining their longer-term role in ex-ante risk-prevention and capacitation at the societal level and securing financial sustainability at the welfare state level. We distinguish three complementary policy functions of SI as theorised by Hemerijck (2017): (1) fostering life-long human capital stock development; (2) easing the flow of family life course transitions; and (3) upholding inclusive social protection buffers in times of need. Next, we conceptualise SI effort in a life course multiplier perspective linking individual returns with cumulative societal gains. We narrow our scope to perhaps the most critical stage in the modern life-cycle course: that of transition into employment and family formation. This is followed by a 'Methodology' section describing the data, the variables used for measuring SI policies, and the operationalisation of SI returns. To our knowledge, this is the first attempt to systematically operationalise SI stock, flow and buffer policy returns in a comprehensive longerterm perspective for families with children. The 'Findings' section presents our results regarding the role of SI policies in explaining employment- and welfare-related outcomes for families with children at a macro level. The last section summarises the findings and discusses their implications.

\section{Social investment policy functions}

Central to the long-term financial sustainability of the welfare state is the number (quantity) and productivity (quality) of current and future employees and taxpayers. To the extent that welfare policy in a knowledge economy is geared towards maximising employability and productivity, this helps to bolster the economic sustainability of the welfare state. The social investment perspective shifts the focus of welfare state provision from ex-post income compensation to ex-ante risk-prevention and capacitation. The objective is to enhance people's opportunities and capabilities to resolve social risks typical of postindustrial societies ex-ante, while ensuring the high levels of (quality) employment necessary to sustain the 'carrying capacity' of popular welfare states. The critical importance of the welfare state's 'carrying capacity' is best understood by the following welfare cost-benefit equation (adapted from Myles, 2002):

$$
\begin{aligned}
& \begin{array}{l}
\text { Carrying capacity of the welfare state }= \\
\text { number of } \\
\frac{\text { welfare recipients }}{\text { number of }} \\
\text { paid workers }
\end{array} \times \frac{\begin{array}{l}
\text { welfare recepients } \\
\text { average productivity of } \\
\text { workers }
\end{array}}{}
\end{aligned}
$$

As briefly mentioned above, the dominant focus in prevailing sociological and political science welfare state research continues to reside with the numerator the distributive side of the equation in terms of the number of welfare clients and their benefit levels. Arguably, the long-term strength of the economy is increasingly contingent on the extent to which social policy can contribute to the (dynamic) productive denominator side of the welfare equation in the knowledge economy against a background of adverse demography. This requires a far wider multi-dimensional ambit of policy interventions across the entire life course. Early child education and care, education and training over the life course, (capacitating) active labour market policies, worklife balance policies like (paid) parental leave, flexible employment relations and work schedules, lifelong learning and long-term care, all share objectives that transcend the compensatory logic of income support, originally developed to protect 
(predominantly male) workers and their (stable) families against market pitfalls.

In this article, we use a conceptual framework for 21 st-century social policy analysis elaborated by Hemerijck $(2015,2017)$ which is based on the operational taxonomy of three interdependent and complementary policy functions of stocks, flows and buffers. Stock policies foster skill acquisition over the life course, generally leading to higher levels of productivity. Flow improves labour utilisation by facilitating life course and labour-market transitions, generally heading to higher levels of employment and lower wage gaps. Buffer policies make sure that individuals and families do not fall between the cracks of the economy when social and/or personal misfortune strikes, hence protecting past human capital investments while also supporting families to safeguard human capital investments in their offspring, which positively affect employment and wages in later years.

It should immediately be acknowledged that there is considerable overlap between the policy functions of stocks, flows and buffers. Policy provisions that at face value privilege one of the three functions typically also back up the other functions in an interconnected fashion. For example, poverty alleviation, principally a 'buffering' policy, can smooth labour market flow, as a consequence of mitigated pressure and background financial stability to accept any job on offer, with the potential benefit of better job matching and less human capital stock depletion. By the same token, high-quality childcare stock-investment facilitates labour market flow especially for working mothers. As such, the concept of 'institutional complementarities' - to borrow a term from the Varieties of Capitalism (VoC) perspective (Hall and Soskice, 2001) - is relevant here. In the VoC literature, a 'set of institutions is said to be complementary to another when its presence raises the returns available from the other' (Hall and Gingerich, 2009: 450). By implication, to the extent that interdependent institutions do not align, they may undermine their synergetic potential.

\section{SI effort in the life course multiplier perspective}

Following the logic of complementarity, SI can be seen as a 'life course multiplier' whereby cumulative
SI returns over the life course generate a cycle of wellbeing, in terms of employment, gender equity and a significant mitigation of intergenerational poverty (see Figure 1). The cycle initiates from early investments in children through good quality early childhood education and care (ECEC) which may translate into better levels of educational attainment and spill over into higher and more productive employment in the medium term (Brilli et al., 2016; Cunha and Heckman, 2007). To the extent that employment participation is supported by work-life balance policies including publicly available childcare, higher levels of (female) employment with potentially lower gender gaps in wages and employment can be foreseen (Del Boca et al., 2005; Korpi et al., 2013; Nieuwenhuis et al., 2012), protecting households against worklessness and poverty (Cantillon and Vandenbroucke, 2014; Härkönen, 2011). Higher and more productive employment, in turn, implies a larger tax base to sustain overall welfare commitments.

The social investment multiplier, in an ideal-typical fashion, captures both micro- and macro-level dynamics. At the micro-level of individuals and households, the multiplier logic suggests how social investments, from early childhood on, improve material wellbeing (employment and income) and help mitigate social risks later in life, through cumulative incentives for skills acquisition and easing (gendered) labour-market transitions over the life course. At the macro-level, the multiplier suggests cumulative societal benefits, ranging from improved productivity, higher employment and lower gender gaps to later retirement and reductions in poverty, all of which are crucial to economic growth and the fiscal sustainability of the welfare states in knowledge economies and ageing societies. The social investment multiplier logic, theoretically, links between various institutional and socio-economic factors that jointly generate individual and collective benefits and thus offers a basis for theoretical propositions and hypothesis generation. The model causally links individuals' social investment life course returns with cumulative gains at the societal level.

Coming back to the Matthew effect conundrum, it is important to point out that in this literature stock and flow services and regulation are considered as substitutes for buffer transfers, not as complementarities. 




Figure I. The social investment life-course multiplier at a micro- and macro-level. Source: Authors' elaboration of Hemerijck (2017: 26).

Matthew effect scholarship treats capacitating social investments as anathema to passive social protection buffer policies. A universal ECEC programme, for instance, is assumed to privilege middle-class families capable of purchasing childcare services in the market, leading to an increase in inequality (Cantillon and Van Lancker, 2013). This conjures up an image of public finance misuse through ECEC outlays that would be better spent on family benefits for work-poor families to generate more immediate redistributive effect. Whether flow and stock policies crowd-in or crowdout social protection buffers and for whom, we maintain, is a matter of methodologically perceptive empirical research, based on available evidence, to which we turn in the next sections.

\section{Transition into employment and family formation}

With the expansion of women's employment over the past quarter century, the work-income-family nexus takes a central place in the social investment paradigm. More flexible labour markets and skill-biased technological change coupled with higher divorce rates and lone-parenthood make economic independence and equal access to employment for both men and women a prerequisite. For this reason the agendasetting interdisciplinary volume Why We Need a New Welfare State called for a 'social investment' renewal aimed at reinforcing social resilience over the family life course, with a special attention to female employment and eradication of child poverty (EspingAndersen et al., 2002). Hence, in this article, we focus on families with children to capture a critical life-cycle stage over which two important life events generally take place: career formation to gain economic independence and family formation.

Previous research has by now well established that employment opportunities tend to differ by gender, albeit not to the same extent across countries. In highincome OECD countries, gender gaps in employment tend to intensify around age 30 to $34^{1}$ coinciding with the time which is crucial for establishing economic independence. Also when the gender gap in employment closes for subsequent age-groups, temporary disadvantage can have negative long-term consequences 
for the future level of remuneration at the individual level and for living standards at the household level (Cooke, 2014). Previous research shows that low work intensity and lone parent households are at a higher risk of poverty (Chzhen, 2017; Chzhen and Bradshaw, 2012). As we show in this contribution, couple families with children where only one adult works are also at a higher risk of poverty. This risk group comprises a large share of families with children, but has thus far received little attention. The main focus of our analysis is therefore on employment- and poverty-related outcomes for families with children. Following the life course multiplier model presented in Figure 1, we test the hypothesis that the provision of SI policies targeted at families with children is associated with a higher proportion of dual breadwinner families, a higher proportion of women with children in employment, and lower child poverty.

\section{Methodology}

The empirical analysis in this paper is based on aggregate country-level data to measure the relationship between social investment policy availability and work- and welfare-related outcomes for families with children in high-income OECD countries. In this section we describe the data, variables and research strategy.

\section{Data and sample}

Data on family structure, employment, poverty and social policies are retrieved from the OECD Family Database (OECD, 2020) which provides aggregate family-related indicators. Data on public social assistance spending are retrieved from EUROSTAT (EUROSTAT, 2020). The analysis is based on a sample that ranges between 25 and 34 high-income OECD countries, varying by indicator availability. A full list of countries and indicators is provided in Annex A of the Supplemental Appendix.

\section{Measurement of social investment policies}

Beyond the practical reality that many of the social investment policies functionally overlap, a major difficulty in empirically investigating whether or not SI policies create positive and/or negative familygendered employment and distributive effects is that available OECD and EUROSTAT indicators do not easily allow for a fitting unambiguous operationalisation of country-level SI stock, flows and buffer policy efforts. We have selected two to three variables as proxies to measuring each of the three policy categories at a country level. Most SI policies are measured with a time lag, expressed as an average of the last 10 years before the measurement of SI returns. This is done to reflect the time before the outcome measurement, and to smooth out any period effects and inconsistent jumps in the data. Each of the variables operationalising SI policies is described below. Table 1 presents summary statistics and data sources. TableA.1 in the Supplemental Appendix presents statistics by country.

Stock: Early childhood education and care services. SI stock policy is measured using indicators on ECEC service take-up and public spending. Enrolment in ECEC for 0- to 2-year-olds and for 3- to 5-yearolds is expressed as a percentage of children of the respective age-group enrolled in or using registered ECEC services, preschool or primary school. Enrolment rates are measured with a lag as an average of 2005 to 2016. Public spending on ECEC services is expressed as a percentage of GDP and measured as an average of 2005 to 2015 .

Flow: Family friendly employment relations and paid leave arrangements. SI flow policy is measured using indicators related to workplace practices and paid leave availability to mothers and fathers. The first indicator captures the proportion of employees that have at least some ability to set their own working time arrangements. Flexibility to arrange working time is regarded as one of the key family-friendly workplace arrangements, defined by the OECD as practices that facilitate the reconciliation of work and family life, introduced by firms to complement statutory requirements (OECD, 2020). The second indicator representing SI flow policies is the duration of paid leave arrangements available to mothers and fathers. It shows the length of paid maternity, paternity, parental and home care leave available to parents, expressed in weeks. Cross-country variation is large, starting from no entitlement to paid leave in the 
Table I. Descriptive statistics of indicators operationalising social investment policies.

\begin{tabular}{|c|c|c|c|c|c|c|}
\hline & & Obs. & Mean & $S D$ & Min & Max \\
\hline \multicolumn{7}{|c|}{ Stock } \\
\hline I & $\begin{array}{l}\text { Percent of children enrolled in early childhood education and care } \\
\text { services, age } 0 \text { to } 2 \text { (average from } 2005 \text { to } 2016)^{\mathrm{a}}\end{array}$ & 33 & 31.4 & 16.0 & 4.9 & 60.2 \\
\hline II & $\begin{array}{l}\text { Percent of children enrolled in ECEC services or primary school, age } 3 \\
\text { to } 5 \text { (average from } 2005 \text { to } 2016)^{\mathrm{a}}\end{array}$ & 33 & 85.1 & 12.7 & 48.1 & 100 \\
\hline III & $\begin{array}{l}\text { Public expenditure on ECEC services, as \% of GDP (average from } 2005 \\
\text { to } 2015)^{\mathrm{a}}\end{array}$ & 31 & 0.7 & 0.3 & 0.35 & 1.6 \\
\hline \multicolumn{7}{|c|}{ Flow } \\
\hline I & $\begin{array}{l}\text { Proportion }(\%) \text { of employees with at least some ability to set their own } \\
\text { working time arrangements }(2015)^{\mathrm{a}}\end{array}$ & 25 & 36.3 & 15.4 & 12.0 & 63.2 \\
\hline II & $\begin{array}{l}\text { Duration of paid maternity, parental and home care leave available to } \\
\text { mothers and fathers, in weeks }(2016)^{\mathrm{a}}\end{array}$ & 34 & 66.3 & 47.2 & 0.0 & 170 \\
\hline \multicolumn{7}{|c|}{ Buffer } \\
\hline I & $\begin{array}{l}\text { Social protection expenditure on housing and social exclusion, as \% of } \\
\text { GDP }(2005-2016)^{b}\end{array}$ & 26 & 0.8 & 0.6 & 0.1 & 2.1 \\
\hline II & $\begin{array}{l}\text { Public expenditure on family benefits (cash, services and tax measures), } \\
\text { in per cent of GDP (2005-2015) }\end{array}$ & 34 & 2.5 & 0.9 & 1.0 & 3.8 \\
\hline III & $\begin{array}{l}\text { Proportion of previous earnings replaced by paid leave benefits for } \\
\text { an individual on average earnings, expressed in weeks of full-rate } \\
\text { equivalent for mothers and fathers }(2016)^{\mathrm{a}}\end{array}$ & 34 & 35.5 & 21.6 & 0 & 87 \\
\hline
\end{tabular}

Sources: a OECD Family Database (OECD, 2020); bEUROSTAT (EUROSTAT, 2020).

Sample: high-income OECD member states; Stock: early childhood education and care services.

United States, up to more than 2 years of paid leave entitlements in Estonia, Finland, Hungary and the Slovak Republic (see Table A.1, Supplemental Appendix). For the measurement of flow policies, the most recent available data were selected since timeseries data for the selected indicators are currently unavailable. Since parental leave policies and employment laws in OECD countries experienced a relatively high institutional stability over the last decade, ${ }^{2}$ we do not expect the use of the most recent data for flow policies to introduce a bias in the results.

Buffer: Social assistance, family benefits and paid leave. SI buffer policy is measured by variables capturing social assistance, family benefits and paid leave available to parents. The first indicator representing buffer policies more broadly is public expenditure on social assistance programmes related to housing and social exclusion expressed as a percentage of GDP (EUROSTAT, 2020). Public expenditures are measured with a time lag and smoothened over 10 years, expressed as an average of 2005 to 2016 . The second indicator is public spending on families, covering family benefits in cash, services and tax measures. Family benefits include public support that is exclusively for families such as child payments and allowances, parental leave benefits, income support for sole parents, spending on services such as childcare subsidisation, centre-based facilities, home help services and tax exemptions and tax credits for families with children. Public spending on families is expressed as a percentage of GDP and measured as an average between 2005 and 2015.

The third indicator representing SI buffer policies is the average payment rate of paid leave available to mothers and fathers. It refers to the proportion of previous earnings replaced by the benefit over the duration of paid leave for a person earning average national earnings (OECD, 2020). Most countries provide benefits that replace around $40 \%$ to $60 \%$ of previous earnings, although this varies across countries. The lowest payment rates tend to be found in countries with the longest entitlements, such as in the Slovak Republic and Finland, driven by the presence 
of extended home care leave entitlements which generally offer medium-term financial support replacing only a small proportion of previous earnings. Because payment rates vary across countries and types of leave, entitlements are presented in a form of 'fullrate equivalent', which is the length of the paid leave in weeks if it were paid at $100 \%$ of previous earnings, derived by multiplying the duration of leave in weeks and the average earnings replacement rate received.

\section{Operationalisation of SI returns for families with children}

SI returns are operationalised as people's work- and welfare-related life outcomes in the medium-term during the time of family formation, measured with most recent available data retrieved from the OECD Family Database (OECD, 2020). We consider two types of outcomes: economic independence measured by employment status of adults in couple- and single-adult families with children; and living conditions measured by poverty rates among couple- and single-adult families with children. Table 2 shows summary statistics of the outcome variables considered. Table A. 2 of the Supplemental Appendix shows statistics by country.

Employment and economic independence. Three indicators have been selected as proxies for measuring employment outcomes among families with children. The first indicator refers to two-adult single-bradwinner families, expressed as a share of children in couple households with only one adult working full time and one adult not working. It includes all families with one adult couple (married or co-habiting) and children aged 0 to 14 . The second indicator captures employment rates for women who live with a spouse or a cohabiting partner and at least one child aged 0 to 14 . The third indicator reflects the proportion of children of age 0 to 14 in single-adult households with a jobless adult. In most cases the adult is the child's parent, but may also be another relative such as an older sibling, grandparent or a guardian.

Living conditions: Poverty. Family welfare and living conditions are captured with indicators related to poverty in families with children. The first indicator is child income poverty, defined as the percentage of children under age 18 with an equalised household disposable income below the poverty threshold of $50 \%$ of the median disposable income in each country. The second indicator is poverty in households with two adults and children by household employment status, expressed as the proportion of individuals in households with two or more adults and at least one child under age 18 with an equalised household disposable income below $50 \%$ of the median disposable income in each country. We compare poverty rates among 'two-breadwinner families' where two adults work, and 'single breadwinner families' where only one adult in couple-households with children is in paid employment. The third indicator concerns poverty in lone-parent households representing the proportion of individuals in households with a single adult of working age and at least one child of age 0 to 17 with an equalised household disposable income below the poverty threshold set at $50 \%$ of the median disposable income in each country.

\section{Research strategy}

The aim of the empirical analysis is to identify the direction and strength of association between SI policies and work- and welfare-related outcomes for families with children at a macro level. We perform bivariate analyses and report two statistical measures: the strength and the slope of association. The strength of association is reported using the adjusted $R$-squared measure (henceforth $R^{2}$ ) - the coefficient of determination showing the percentage of variation in the dependent variable that is explained by the explanatory variable. The closer the $R^{2}$ is to 1 , the stronger the association. The slope indicates the direction of association, showing whether the estimated association is positive or negative. Data are plotted in scatterplots to provide with a visual check of the relationship, with each point representing a country. SI policies and outcomes are plotted on the horizontal and vertical axes, respectively. The analysis is descriptive and does not imply causality.

In addition to bivariate associations, we perform multivariate regression analyses controlling for countries' economic development and the overall welfare state size. This is done to minimise the risk 
Table 2. Descriptive statistics of work- and welfare-related outcomes for families with children.

\begin{tabular}{|c|c|c|c|c|c|c|}
\hline & & Obs. & Mean & SD & Min & Max \\
\hline \multicolumn{7}{|c|}{ Employment in households with children } \\
\hline I & $\begin{array}{l}\text { Single-breadwinner families: share of children (aged 0-14) in couple } \\
\text { households where only one adult works }(2018)\end{array}$ & 25 & 26.8 & 8.2 & 13.9 & 38.9 \\
\hline II & $\begin{array}{l}\text { Employment rates (\%) for partnered women with one or more } \\
\text { children aged } 0 \text { to } 14(20 \mid 4)\end{array}$ & 30 & 68.9 & 9.4 & 48.5 & 84.6 \\
\hline III & $\begin{array}{l}\text { Share of children (aged } 0-14) \text { in single-parent households where the } \\
\text { adult is jobless (2018) }\end{array}$ & 25 & 29.4 & 8.7 & 13.0 & 47.5 \\
\hline \multicolumn{7}{|c|}{ Poverty in households with children } \\
\hline I & Child income poverty rate, aged 0 to 17 (2017) & 33 & 12.5 & 5.0 & 3.6 & 23.7 \\
\hline \multicolumn{7}{|c|}{ II Poverty rate in families with two or more adults and children where } \\
\hline & o adults work (2014) & 32 & 3.8 & 2.7 & 0.7 & 11.4 \\
\hline \multicolumn{2}{|c|}{ One adult works (2014) } & 32 & 20.8 & 10.1 & 4.5 & 47.3 \\
\hline III & Poverty rate in single-adult families with children (2017) & 33 & 32.2 & 10.5 & 8.2 & 52.9 \\
\hline
\end{tabular}

Source: OECD Family Database (OECD, 2020).

Sample: high-income OECD member states.

of identifying spurious associations stemming from contextual macroeconomic differences between countries. The methodology and detailed results of multivariate analyses are reported in Annexes B and $\mathrm{C}$ of the Supplemental Appendix. Placebo tests are also performed to assess if the identified effects of SI policies do not exist when passive social protection policies are considered. A detailed description and findings of placebo tests are presented in Annex D of the Supplemental Appendix. Main findings are summarised in the 'Findings' section.

\section{Findings}

\section{The role of SI policies in explaining employment outcomes for families with children}

We begin our analysis by studying the association between stock policies and employment outcomes. The SI stock policy considered here is formal childcare. ${ }^{3}$ Findings show that limited childcare availability is strongly associated with a single breadwinner model. Countries with the lowest childcare participation rates and the lowest public spending on ECEC services have the highest share of children living in households where only one of the two adults works. The proportion of children aged 0 to 2 attending formal childcare explains more than one third of the overall variation in the share of children living in single breadwinner households across high-income OECD countries $\left(R^{2}=0.40\right.$, Figure $\left.2 \mathrm{a}\right)$. Similarly, there is a strong and positive association between childcare participation and employment rates among partnered women with children $\left(R^{2}=0.35\right.$, Figure $\left.2 b\right)$. The size of these associations remains substantial and statistically significant also when controlling for countries' economic development and the welfare state size (see Supplemental Appendix Table B.1). At the same time, investments and take-up of ECEC services are weakly associated with lone-parent employment (Figure 2c). Both bivariate and multivariate OLS regressions show that this association is weak and statistically insignificant. Most of the cross-country variation in the proportion of children in jobless single-parent households remains unexplained. This implies that other factors than access to childcare account for lone parents' employment status.

We now turn to SI flow policies, starting with flexible working time arrangements deemed as important for family-work life reconciliation. Figure 3 reveals that the higher the access to flexible working time arrangements, the lower the share of children living in single breadwinner households $\left(R^{2}=0.22\right.$, Figure $\left.3 \mathrm{a}\right)$, and the higher the employment rate for partnered women with children $\left(R^{2}=0.36\right.$, Figure $\left.3 \mathrm{~b}\right)$. These 


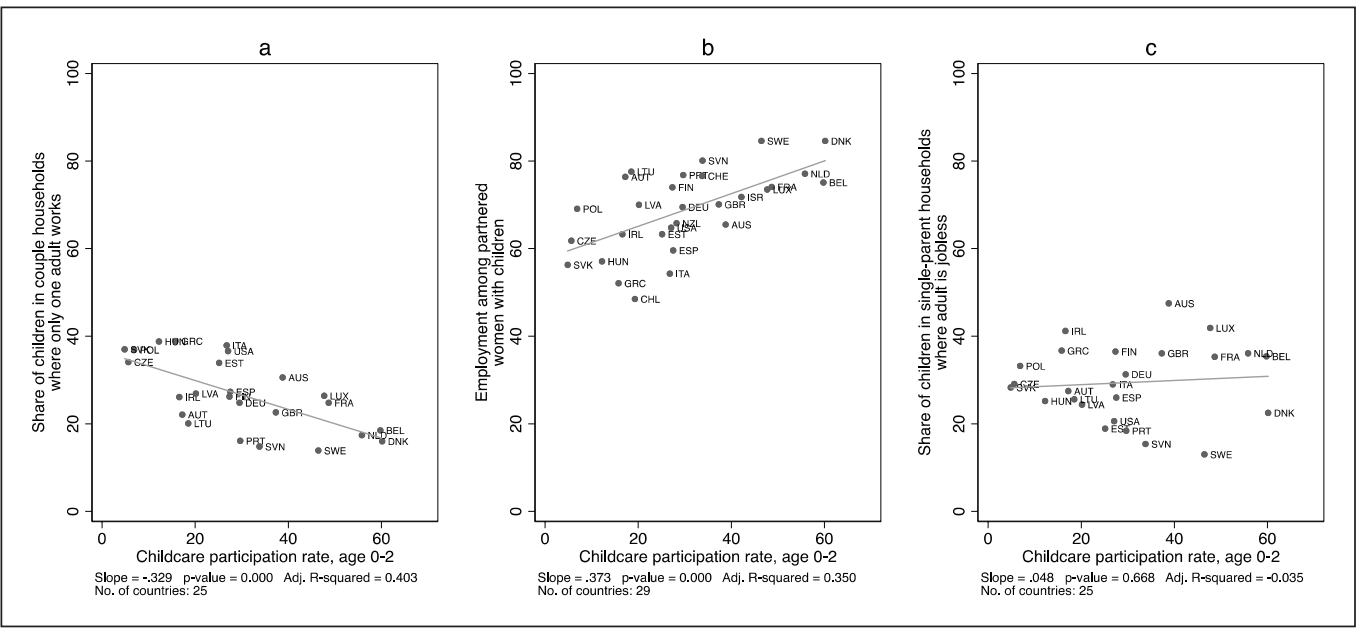

Figure 2. Association between ECEC and parental employment.

findings suggest that in countries with family-friendly workplace practices, parents with children are more capable of reconciling their work- and family-life and are more likely to follow a dual-breadwinner model. These associations remain substantial and statistically significant also when controlling for countries' per capita GDP and the overall size of the welfare state (Supplemental Appendix Table B.1). For lone-parent households with children, by contrast, the association between employees' flexibility to set working time and the employment status is weak and is not statistically significant (Figure 3c).

The second SI flow policy that we consider is paid leave duration for parents. A polynomial squared term of duration was introduced to allow for diminishing or increasing effects for leave duration (explained more in detail in Annex B, Supplemental Appendix). We have tentative evidence of a U-shape association between the length of paid leave and parental employment of couple families with children. The share of two-adult single breadwinner families seems to be higher in countries with a very low and a very high paid leave duration. Similarly, employment rates among partnered women with children tend to be lower in countries concentrated at both extremes of the distribution of paid leave duration. These associations, however, have a high level of uncertainty and the estimated slope is not statistically significant. Bivariate and multivariate results are reported in Figure B.1 and Table B.1 of the Supplemental Appendix.

\section{The role of SI policies in explaining variation in poverty for families with children}

Figure 4 shows association between stock and flow SI policy availability and child poverty. Associations shown in Figure $4 a$ and $b$ reveal that countries with higher public investments in ECEC services and a higher share of employees with at least some flexibility to arrange working time have a substantially lower risk of child poverty. These associations remain substantial and statistically significant also when accounting for country differences in per capita GDP and overall spending on social cash benefits (see Supplemental Appendix Table B.2). Flexibility to set working time arrangements explains more than one third of variation in child poverty rates across countries $\left(R^{2}=0.35\right)$, while public spending on ECEC services explains about one fourth of this variation $\left(R^{2}=0.24\right)$.

Figure $4 \mathrm{c}$ suggests a negative association between paid leave duration and child poverty up until around 100 weeks of paid leave duration, after which the slope flattens out. Some of the countries with the highest child poverty rates also have the lowest paid leave duration. These are the United States, Spain 


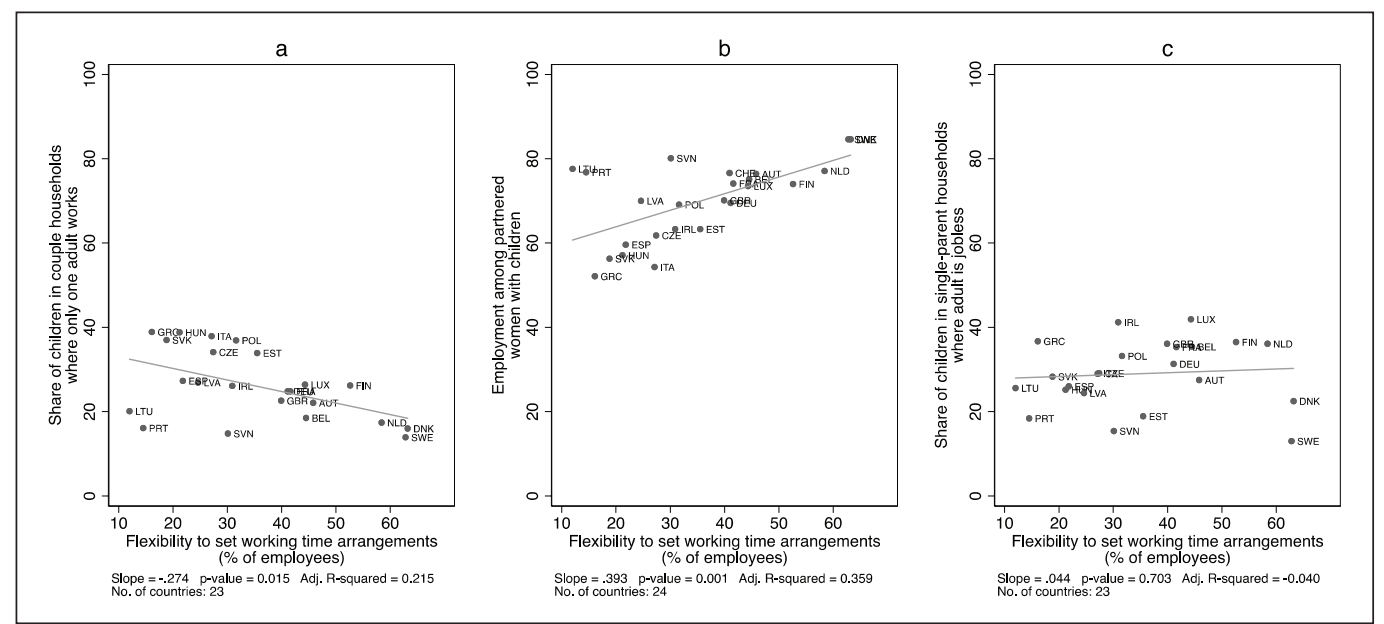

Figure 3. Association between flexibility to arrange working time and parental employment.

and Chile. For countries with average and high leave duration, no relationship with child poverty can be observed. We have introduced a polynomial term of paid leave duration since accounting for non-linearity of the association improves the model. The association, however, is not statistically significant at a $95 \%$ level (see also Supplemental Appendix Table B.2). We therefore cannot claim with certainty that paid leave duration is associated with child poverty.

Figure 5 shows association between buffer policy provision targeted at families with children and child poverty rates. Findings indicate that there is a strong and negative association between social assistance and child poverty (Figure 5a) and family benefits and child poverty (Figure $5 \mathrm{~b}$ ). These associations remain significant and the coefficient size drops very marginally when controlling for macroeconomic differences between countries (Supplemental Appendix Table B.2). We also tested whether higher earnings replacement rates by paid leave are associated with lower child income poverty rates (Figure $5 \mathrm{c}$ ). This association is negative and statistically significant but has a high level of uncertainty $(p$-value $=0.09)$. When national GDP per capita is controlled for, the slope of the association becomes steeper and statistical certainty increases (slope $=-0.11, p$-value $=0.01$; Supplemental Appendix Table B.2). This finding reveals that net of differences in economic development, countries with a higher earnings replacement from paid leave benefits tend to have lower child poverty rates.

We have further explored the relationship between one of the main SI buffer policies - public spending on family benefits - and poverty rates among families with children. The associations show that the higher the public spending on family benefits at a macro level, the lower the poverty rates among families with children. The effect size remains substantial and statistically significant also when controlling for differences in the macroeconomic indicators (see Supplemental Appendix, Annex C). We also find that spending on family benefits does not fully compensate for the lack of family income, especially among single-breadwinner and lone-parent families. For these two types of families, poverty rates are considerable also in countries with relatively high public spending on family benefits (Annex C, Supplemental Appendix). Poverty rates are close to zero only in countries where most families with children have two employed adults and where public spending on family benefits is the highest.

\section{Alternate policies as placebo tests}

To test the plausibility of our identification assumptions, we verified if the effects of SI policies that we identified do not exist when we substitute them with alternate policies. SI policies were replaced with 


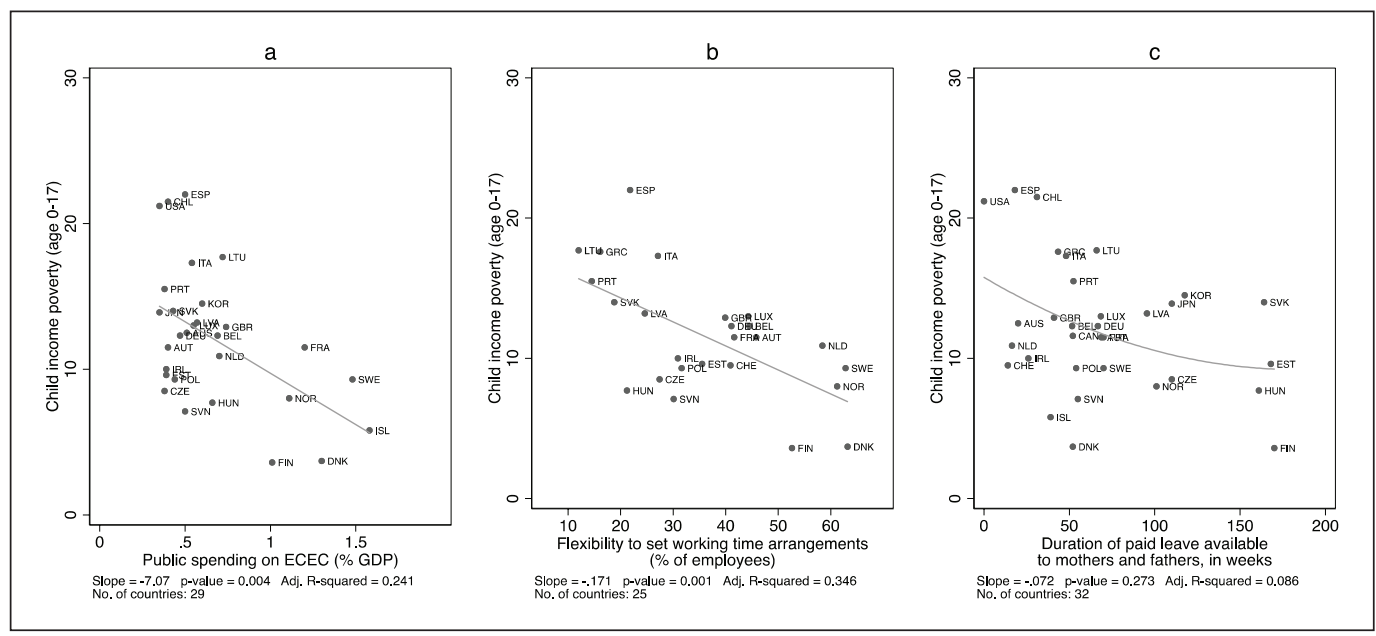

Figure 4. Association between stock and flow SI policies and child income poverty.

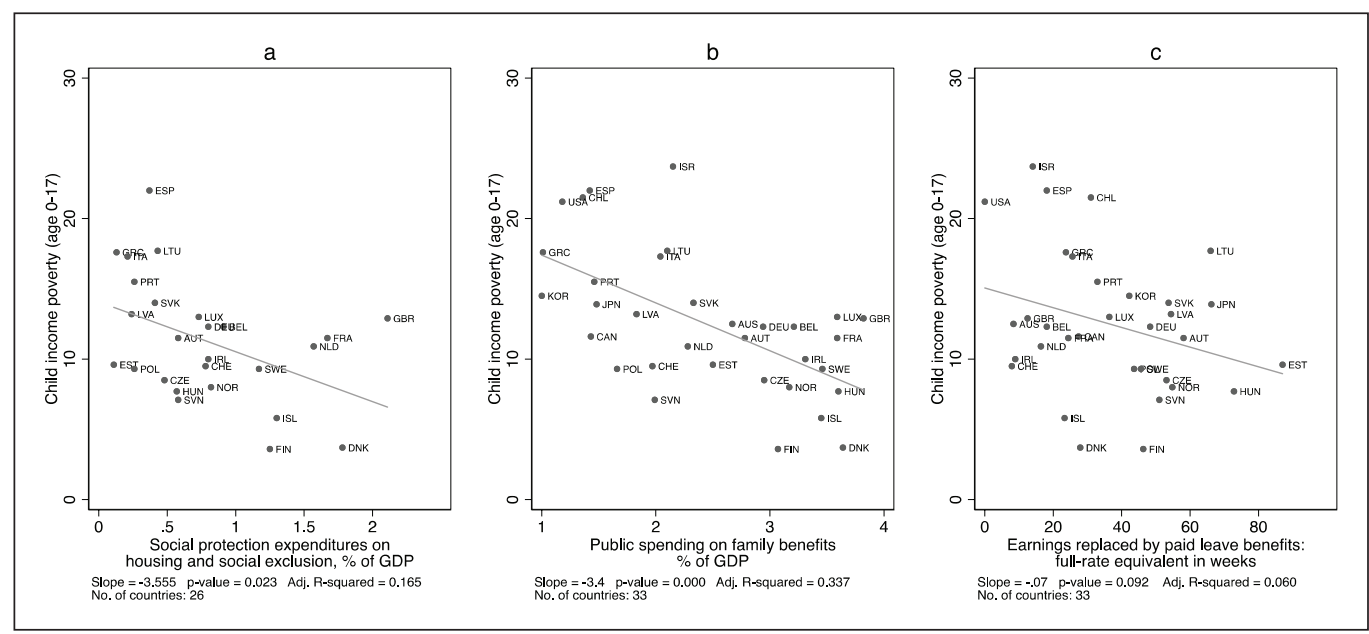

Figure 5. Association between buffer policies and child income poverty.

passive social protection programmes and the overall social cash benefits. Findings show that public spending on pensions and unemployment have a weak and statistically non-significant association with parental employment and child poverty rates. The test also reveals that the total social cash benefit size (as \% of GDP) is not a good predictor for parental employment rates and poverty rates among couple families with children. Results are reported in Annex D of the Supplemental Appendix. Overall, our findings signal that stock, flows and buffer policies specifically targeted at families with children have a strong (and statistically significant) positive relationship with employment and wellbeing outcomes for couple families with children, while this is not the case with passive social protection policies and the overall welfare state generosity. For lone-parent families, by contrast, spending on social benefits explains a large part of cross-country differences in poverty rates. The higher the overall spending on social benefits in cash, the lower the poverty rates among lone-parent families, also net of family benefits and per capita GDP (Table 
C.1, Supplemental Appendix). This could be expected since lone-parent families need additional support beyond SI policies.

\section{Conclusion}

The main research question addressed in this paper was whether SI policies allow for greater economic independence and welfare among families with children for couple- and single-parent households at a societal level. Our main aim was to improve the conceptualisation and measurement of social investment policy returns, shifting from short-term effects measured by pre- and post-transfer disposable household income to more medium-term effects. As such, this is the first social science effort to examine stock, flows and buffer policy efforts on employment and redistribution over the critical life course stage of the transition into employment and family formation.

Our analyses of stock, flows and buffer policies concur positive returns in employment and poverty mitigation across OECD countries. In countries with higher childcare investments and take-up, more familyfriendly workplace practices, and higher social assistance and family benefits, families with children are more capable of reconciling their work- and familylife, are more likely to follow a dual-breadwinner model, and have lower child poverty rates. Our findings thus rejuvenate Nolan's rhetorical question on the use of social investment and question Cantillon's Matthew effect critique that social investment reform disproportionately benefits better-off households at the expense of poor families. A swath of prior research has identified such Matthew effects when looking at the short-term SI policy returns at the individual level. In this article, we show that when extending the scope of this research to medium-term returns, positive employment- and wellbeing-related outcomes at the societal level are observed.

In terms of the effect of SI policies on employment, findings indicate that: (1) Higher ECEC spending and enrolment, with the potential of raising long-term human capital stock, are associated with a lower share of children living in single-breadwinner families and with higher employment rates for partnered mothers; (2) A higher share of employees with flexible working time arrangements, thereby improving flow, is also associated with a lower share of children living in single-breadwinner families and with higher employment rates for partnered mothers; (3) The association between paid leave duration, easing labour market flow, and employment status among families with children tends to have a reverse U-shape, with lower dualearner rates and lower employment rates among partnered mothers in countries with a very low and a very high paid leave duration ${ }^{4}$; and (4) Stock and flow SI policy availability does not have any notable association with employment outcomes for lone-parent families.

Regarding the association between SI policies and living conditions, findings show that: (1) Stock, flows and buffer SI policy-availability is negatively associated with child poverty; (2) Family benefits are associated with lower poverty rates among families with children for both, couple- and lone-parent households, but spending on family benefits does not fully compensate for the lack of family income, especially among single-breadwinner and loneparent families with children.

The main takeaway is that when moving from short- to medium-term returns to SI policies at a societal level, a positive association emerges between social investment policies and outcomes in employment and living conditions for families with children. One of the limitations of this analysis is that SI policies are analysed one by one disregarding possible interaction effects, while there is indication from previous research that such interaction effects exist (Bradley and Stephens, 2007; Dräbing and Nelson, 2017). More in-depth qualitative follow-up analyses are needed to uncover the concrete (joint) effects of social investment policies. In this analysis, we assessed SI returns only descriptively without causal inference using cross-sectional macro-level data. Future research will have to address the channels through which stock, flows and buffer policies affect micro-level wellbeing in a longitudinal perspective. In this respect, our research is merely the first systematic estimation of the macro-sociological baseline argument about wellbeing returns to social investment.

\section{Acknowledgements}

This paper has benefited from multiple discussions regarding the welfare state future and solidarity, 
including the Annual ESPAnet Conference 2018, the State of the Union 2018 panel on Social Investment in the Balance and the methodological workshop on wellbeing returns on social investment organised at the European University Institute in June 2018. The authors are particularly grateful to Yekaterina Chzhen, Stefano Ronchi and Simon Vydra for all their insightful comments on previous versions of this work, as well as two anonymous reviewers for their rigorous review and valuable suggestions.

\section{Funding}

The author(s) received no financial support for the research, authorship and/or publication of this article.

\section{Supplemental material}

Supplemental material for this article is available online.

\section{Notes}

1. According to employment profiles over the life course provided by the OECD Family Database (OECD, 2020), gender gap in employment across OECD countries on average increased from 15\% points at age 25 to 29 to as high as $21 \%$ points by age 30 to 34 .

2. The OECD reports stability in job protection legislation and the length of paid leave between 2000 and 2018, with minor exceptions. For a detailed number of weeks of paid leave entitlements and changes over time, see excel spreadsheet entitled 'Trends in parental leave policies since 1970' available in the OECD Family Database (OECD, 2020).

3. Findings presented here are based on enrolments in ECEC among children aged 0 to 2 . The associations using the other two stock indicators - preschool participation at age 3 to 5 and public spending on ECEC services - have the same pattern as in Figure 2, albeit with a weaker strength of association. Results can be provided by authors upon request.

4. The estimated slopes are not statistically significant at a $95 \%$ level. Thus, we cannot be certain that the U-shape association was not identified by chance. This ambiguity reflects differences in the design of child allowances, which in many countries, until recently, were intended to discourage maternal employment, while in others paid leaves are targeted to accommodate worklife and family reconciliation and encourage employment participation (Bradley and Stephens, 2007; Nelson and Stephens, 2012).

\section{References}

Abrassart, A. and Bonoli, G. (2015) 'Availability, Cost or Culture? Obstacles to Childcare Services for LowIncome Families', Journal of Social Policy 44(4): 787-806.

Bradley, D.H. and Stephens, J.D. (2007) 'Employment Performance in OECD Countries: A Test of Neoliberal and Institutionalist Hypotheses', Comparative Political Studies 40(12): 1486-1510.

Brilli, Y., Del Boca, D. and Pronzato, C.D. (2016) 'Does Child Care Availability Play a Role in Maternal Employment and Children's Development? Evidence from Italy', Review of Economics of the Household 14(1): $27-51$.

Cantillon, B. (2011) 'The Paradox of the Social Investment State: Growth, Employment and Poverty in the Lisbon Era', Journal of European Social Policy 21(5): 432-49.

Cantillon, B. and Van Lancker, W. (2013) 'Three Shortcomings of the Social Investment Perspective', Social Policy and Society 12(4): 553-64.

Cantillon, B. and Vandenbroucke, F. (2014) Reconciling Work and Poverty Reduction: How Successful Are European Welfare States? Oxford: Oxford University Press.

Chzhen, Y. (2017) 'Unemployment, Social Protection Spending and Child Poverty in the European Union During the Great Recession', Journal of European Social Policy 27(2): 123-37.

Chzhen, Y. and Bradshaw, J. (2012) 'Lone Parents, Poverty and Policy in the European Union', Journal of European Social Policy 22(5): 487-506.

Cooke, L.P. (2014) 'Gendered Parenthood Penalties and Premiums Across the Earnings Distribution in Australia, the United Kingdom, and the United States', European Sociological Review 30(3): 360-72.

Cunha, F. and Heckman, J. (2007) 'The Technology of Skill Formation', The American Economic Review 97(2): 31-47.

Del Boca, D., Locatelli, M. and Vuri, D. (2005) 'ChildCare Choices by Working Mothers: The Case of Italy', Review of Economics of the Household 3(4): 453-77.

Dräbing, V. and Nelson, M. (2017) 'Addressing Human Capital Risks and the Role of Institutional Complementarities', in A. Hemerijck (ed.) The Uses of Social Investment, pp. 128-39. Oxford: Oxford University Press.

Esping-Andersen, G. (1990) The Three Worlds of Welfare Capitalism. Princeton, NJ: Princeton University Press. 
Esping-Andersen, G., Gallie, D., Hemerijck, A. and Myles, J. (2002) Why We Need a New Welfare State. Oxford: Oxford University Press.

European Commission (2019) Employment and Social Developments in Europe. Sustainable Growth for All: Choices for the Future of Social Europe. Luxembourg: Publications Office of the European Union.

EUROSTAT (2020) 'Database - Eurostat Statistics', available at: https://ec.europa.eu/eurostat/data/database (accessed 8 January 2020).

Garritzmann, J.L., Busemeyer, M.R. and Neimanns, E. (2018) 'Public Demand for Social Investment: New Supporting Coalitions for Welfare State Reform in Western Europe?', Journal of European Public Policy 25(6): 844-61.

Hall, P.A. and Gingerich, D.W. (2009) 'Varieties of Capitalism and Institutional Complementarities in the Political Economy: An Empirical Analysis', British Journal of Political Science 39(3): 449-82.

Hall, P.A. and Soskice, D. (eds) (2001) Varieties of Capitalism: The Institutional Foundations of Comparative Advantage. Oxford: Oxford University Press.

Härkönen, J. (2011) 'Children and Dual Worklessness in Europe: A Comparison of Nine Countries', European Journal of Population/Revue européenne de Démographie 27(2): 217-41.

Hemerijck, A. (2015) 'The Quiet Paradigm Revolution of Social Investment', Social Politics: International Studies in Gender, State and Society 22(2): 242-56.

Hemerijck, A. (2017) The Uses of Social Investment. Oxford: Oxford University Press.

Huo, J. (2009) Third Way Reforms: Social Democracy After the Golden Age. Cambridge: Cambridge University Press.

Korpi, W., Ferrarini, T. and Englund, S. (2013) 'Women's Opportunities Under Different Family Policy Constellations: Gender, Class, and Inequality Tradeoffs in Western Countries Re-examined', Social Politics: International Studies in Gender, State \& Society 20(1): 1-40.
Kuitto, K. (2016) 'From Social Security to Social Investment? Compensating and Social Investment Welfare Policies in a Life course Perspective', Journal of European Social Policy 26(5): 442-59.

Myles, J. (2002) 'A New Social Contract for the Elderly?', in G. Esping-Andersen, D. Gallie, A. Hemerijck and J. Myles (eds) Why We Need a New Welfare State, pp. 130-72. Oxford: Oxford University Press.

Nelson, M. and Stephens, J.D. (2012) 'Do Social Investment Policies Produce More and Better Jobs?', in M. Nathalie and P. Bruno (eds) Towards a Social Investment Welfare State? Ideas, Policies and Challenges, pp. 205-34. Bristol: Policy Press.

Nieuwenhuis, R., Need, A. and Van der Kolk, H. (2012) 'Institutional and Demographic Explanations of Women's Employment in 18 OECD Countries, 19751999', Journal of Marriage and Family 74(3): 614-30.

Nolan, B. (2013) 'What Use is "Social Investment"?', Journal of European Social Policy 23(5): 459-68.

Nolan, B. (2017) 'Social Investment: The Thin Line between Evidence-Based Research and Political Advocacy', in A. Hemerijck (ed.) The Uses of Social Investment, pp. 43-50. Oxford: Oxford University Press.

OECD (2014) All on Board: Making Inclusive Growth Happen. Paris: OECD Publishing.

OECD (2020) 'OECD Family Database, OECD Social Policy Division, Directorate of Employment, Labour and Social Affairs', available at: http://www.oecd.org/ els/family/database.htm (accessed 8 January 2020).

Ronchi, S. (2018) 'Which Roads (If Any) to Social Investment? The Recalibration of EU Welfare States at the Crisis Crossroads (2000-2014)', Journal of Social Policy 47(3): 459-78.

van Kersbergen, K. and Hemerijck, A. (2012) 'Two Decades of Change in Europe: The Emergence of the Social Investment State', Journal of Social Policy 41(3): 475-92.

World Bank Group (2016) Poverty and Shared Prosperity 2016: Taking on Inequality. Washington, DC: World Bank. 